Article

\title{
Bienzymatic Cascade for the Synthesis of an Optically Active O-benzoyl Cyanohydrin
}

\author{
Laura Leemans ${ }^{1,2}$, Luuk van Langen ${ }^{2}\left(\mathbb{D}\right.$, Frank Hollmann ${ }^{3}\left(\mathbb{D}\right.$ and Anett Schallmey ${ }^{1, *} \mathbb{( D}$ \\ 1 Institute for Biochemistry, Biotechnology and Bioinformatics, Technische Universität Braunschweig, \\ Spielmannstr. 7, 38106 Braunschweig, Germany; 1.leemans-martin@tu-braunschweig.de \\ 2 Viazym B.V., Molengraaffsingel 10, 2629 JD Delft, The Netherlands; vanlangen@viazym.nl \\ 3 Department of Biotechnology, Delft University of Technology, Van der Maasweg 9, 2629 HZ Delft, \\ The Netherlands; f.hollmann@tudelft.nl \\ * Correspondence: a.schallmey@tu-braunschweig.de; Tel.: +49-531-391-55400
}

Received: 14 May 2019; Accepted: 10 June 2019; Published: 12 June 2019

\begin{abstract}
A concurrent bienzymatic cascade for the synthesis of optically pure (S)-4-methoxymandelonitrile benzoate ((S)-3) starting from 4-anisaldehyde (1) has been developed. The cascade involves an enantioselective Manihot esculenta hydroxynitrile lyase-catalyzed hydrocyanation of $\mathbf{1}$, and the subsequent benzoylation of the resulting cyanohydrin (S)-2 catalyzed by Candida antarctica lipase A in organic solvent. To accomplish this new direct synthesis of the protected enantiopure cyanohydrin, both enzymes were immobilized and each biocatalytic step was studied separately in search for a window of compatibility. In addition, potential cross-interactions between the two reactions were identified. Optimization of the cascade resulted in $81 \%$ conversion of the aldehyde to the corresponding benzoyl cyanohydrin with $98 \%$ enantiomeric excess.
\end{abstract}

Keywords: Enantioselectivity; enzyme cascade; hydroxynitrile lyase; lipase; hydrocyanation; transesterification

\section{Introduction}

In the past decades, the field of biocatalysis has grown exponentially, becoming an industrially attractive technology for the production of chiral pharmaceutical intermediates and precursors in the synthesis of fine chemicals [1,2]. Recently, considerable progress has been made in developing enzymatic cascades for the production of valuable chemical products [3-6]. These are synthetic processes that combine two or more enzymes in one pot and can be performed in a concurrent (simultaneous) or sequential mode [7]. The combination of individual reaction steps in a one-pot process has several advantages in terms of process efficiency and sustainability, since the solvent consumption and waste generation is generally decreased due to the lower number of work-up steps [5]. Furthermore, the coupling of reactions has the potential to drive equilibria towards the desired products, hence reducing the required excess of reagents [8]. There are, however, some challenges associated with the design of enzymatic cascades, mainly due to enzymes often having different optimum conditions. Furthermore, the presence of side products of certain reactions may lead to enzyme inhibition, which could be avoided by running the reactions in a sequential mode $[9,10]$.

A current challenge in the field of enzymatic cascades is the coupling of a hydroxynitrile lyase (HNL)-catalyzed cyanohydrin synthesis with an acylation catalyzed by a lipase. The immediate acylation of the formed cyanohydrin could prevent the back reaction from taking place and yield a chemically more stable product. In addition, if a lipase with appropriate enantioselectivity is chosen, the enantiopurity of the final product can be enhanced.

However, the one-pot combination of the two enzymes is not trivial, for they have very different requirements. It is well known that water acts as a competing nucleophile in lipase-catalyzed 
transesterification reactions [11], whereas HNLs require relatively high water content when working in organic solvents [12-14]. Due to these different water content requirements, the cascade synthesis of acylated cyanohydrins catalyzed by an HNL and a lipase is a challenging task. Hanefeld et al. attempted to couple the hydrocyanation of benzaldehyde with the acetylation of the formed mandelonitrile, in order to shift the equilibrium of the first reaction. The reactions were catalyzed by Hevea brasiliensis hydroxynitrile lyase ( $\mathrm{HbHNL}$ ) and Candida antarctica lipase B (CALB), respectively. However, they encountered problems due to hydrolysis of the acyl donor and subsequent deactivation of the HbHNL [10]. As an alternative to the bienzymatic synthesis of acylated cyanohydrins, researchers have studied kinetic resolution of acylated cyanohydrins and dynamic kinetic resolution approaches combining an unselective hydrocyanation with an enantioselective transesterification [15-20]. Nevertheless, it has been shown that under certain conditions HNLs can work at low water content [21], opening the possibility for combining the two mentioned enantioselective enzymatic steps.

In the present study, we have selected the hydrocyanation of 4-anisaldehyde (1) combined with the benzoylation of the formed cyanohydrin (2) to yield 4-methoxymandelonitrile benzoate (3) as a model reaction (Scheme 1). The hydrocyanation of 4-anisaldehyde requires a particularly high excess of HCN to drive the equilibrium towards the cyanohydrin, compared to other benzaldehydes [22-24], which is attributed to the positive mesomeric effect of the para-methoxy substituent. The direct benzoylation of the cyanohydrin was envisioned as a possible solution to avoid isolating this instable product. The obtained cascade product 3 is interesting, as it can be transformed in a single hydrogenation step into $(S)$-tembamide [25], a naturally occurring $N$-( $\beta$-hydroxy) amide for which antiviral (HIV) and hypoglycemic activity have been reported [26,27].

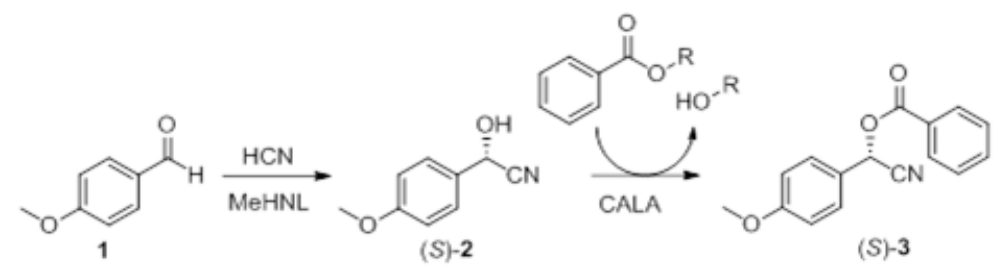

Scheme 1. Proposed cascade synthesis of (S)-4-methoxymandelonitrile benzoate.

Herein, Manihot esculenta hydroxynitrile lyase (MeHNL) - an S-selective enzyme [28] that can catalyze the hydrocyanation of 4-anisaldehyde-was studied. For the benzoylation of the resulting cyanohydrin, Candida antarctica lipase A (CALA) was chosen, which is known to accept bulky substrates and displayed preference for (S)-4-methoxymandelonitrile benzoate in a prior hydrolase screening (see supporting information Table S1 and Figure S1). Moreover, CALA is a robust industrial enzyme, and was shown to exhibit acyltransferase activity even in aqueous media [29], which we deemed an attractive feature in our envisioned cascade.

\section{Results and Discussion}

A crucial step in the development of the intended cascade was the identification of a suitable benzoyl donor that would facilitate the CALA-catalyzed transesterification. Several donors were screened in the CALA-catalyzed benzoylation of 4-methoxymandelonitrile (see Figure S2). Of the screened esters, phenyl benzoate afforded the highest reaction rate.

For a successful combination of $M e H N L$ and CALA in the cascade synthesis of (S)-4-methoxymandelonitrile benzoate, the enzymatic hydrocyanation and transesterification reactions were subjected to a systematic study of the relevant reaction variables. The effects of temperature and water activity on both reactions were evaluated and a suitable carrier was selected for the immobilization of each enzyme. In a preliminary solvent screening, isopropyl ether was selected as reaction solvent due to its compatibility with both enzymes and the relatively high solubility of the substrates. 


\subsection{Influence of Reaction Temperature}

In general, temperature affects enzymatic stability and has a great effect on the reaction rate of enzyme-catalyzed reactions and their enantioselectivity. The influence of temperature on the enantioselectivity of enzymatic reactions can be explained by a simple theoretical model [30]. Depending on whether the reaction takes place below or above the so-called racemic temperature, a decrease in temperature will increase or decrease the enantioselectivity, respectively.

According to literature, $\mathrm{MeHNL}$ shows optimal hydrocyanation activity at $\sim 40^{\circ} \mathrm{C}$ [31]. A reduction in reaction temperature below $40{ }^{\circ} \mathrm{C}$ would decrease enzymatic activity, but is expected to slightly increase its enantioselectivity, since $\mathrm{MeHNL}$ displays an elevated racemic temperature of $580^{\circ} \mathrm{C}$ in the hydrocyanation of phenylpropionaldehyde in dibutylether [14]. Furthermore, decreasing the reaction temperature should reduce the rate of the nonenzymatic hydrocyanation of 4-anisaldehyde to a higher extent than the enzymatic reaction, which would also contribute to increase the enantiomeric excess (e.e.) of the cyanohydrin [32-34]. Finally, the reaction must be performed at a rather low temperature, since the boiling point of $\mathrm{HCN}$ is $25.6^{\circ} \mathrm{C}$ [35]. Based on this information, hydrocyanation reactions were performed at 5,10 , and $20^{\circ} \mathrm{C}$.

Within the studied temperature range, the hydrocyanation rate increased moderately with the reaction temperature (see Figure 1). On the other hand, the enantioselectivity of the enzymatic reaction slightly increased at lower temperatures, as expected. These results suggest that the optimal reaction temperature, which would afford excellent enantioselectivity with a satisfactory reaction rate, would be $10^{\circ} \mathrm{C}$.

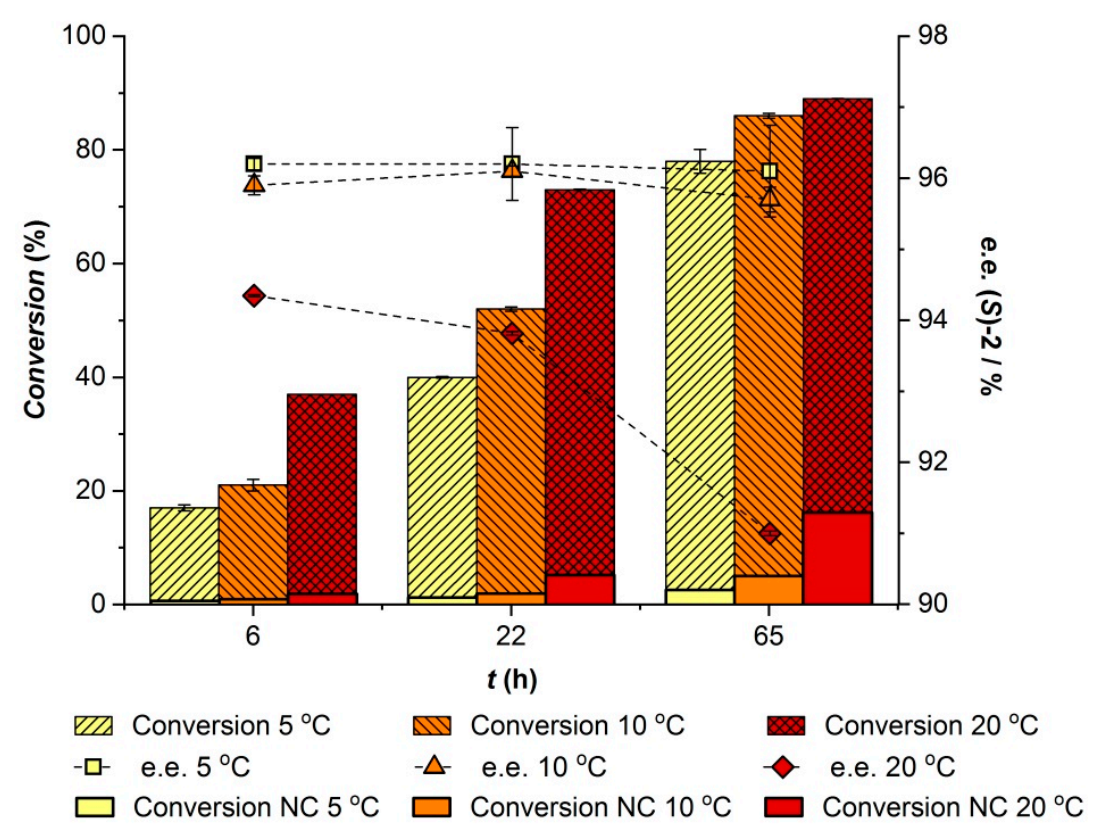

Figure 1. Effect of reaction temperature on the $\mathrm{MeHNL}$-catalyzed hydrocyanation of $100 \mathrm{mM} 4$-anisaldehyde in a biphasic system using 6.5 equivalents of HCN. Negative control (NC) shows the rate of the unselective background reaction.

In the case of CALA, based on the data from kinetic resolution studies, the lipase was expected to show increased enantioselectivity with lower temperatures [36,37]. However, immobilized CALA has been reported to display a temperature optimum of $90{ }^{\circ} \mathrm{C}$ [38], thus the conversion will be limited by low reaction rates at low temperatures.

The effect of reaction temperature on the CALA-catalyzed benzoylation of racemic 4-methoxymandelonitrile was studied in isopropyl ether without added water in the range of 5 to $25^{\circ} \mathrm{C}$. The results showed that, when reducing the temperature, the enantioselectivity of CALA was slightly enhanced (E value of 7 at 5 and $10^{\circ} \mathrm{C}$ and 6 at $25^{\circ} \mathrm{C}$ ), although this was at the expense 
of a pronounced reduction of reaction rate, as shown in Figure 2. Within the studied temperature range, the CALA-catalyzed benzoylation of 4-methoxymandelonitrile can be achieved in relatively high yields with optimal performance at $25^{\circ} \mathrm{C}$. Although CALA shows preference for conversion of the (S)-enantiomer, it is not selective enough to afford an enantiopure product. However, when preceded by an enantioselective hydrocyanation, the transesterification reaction can enhance the enantiopurity of the final product. Therefore, the observed minor effect of reaction temperature on the enantiomeric ratio can be neglected.

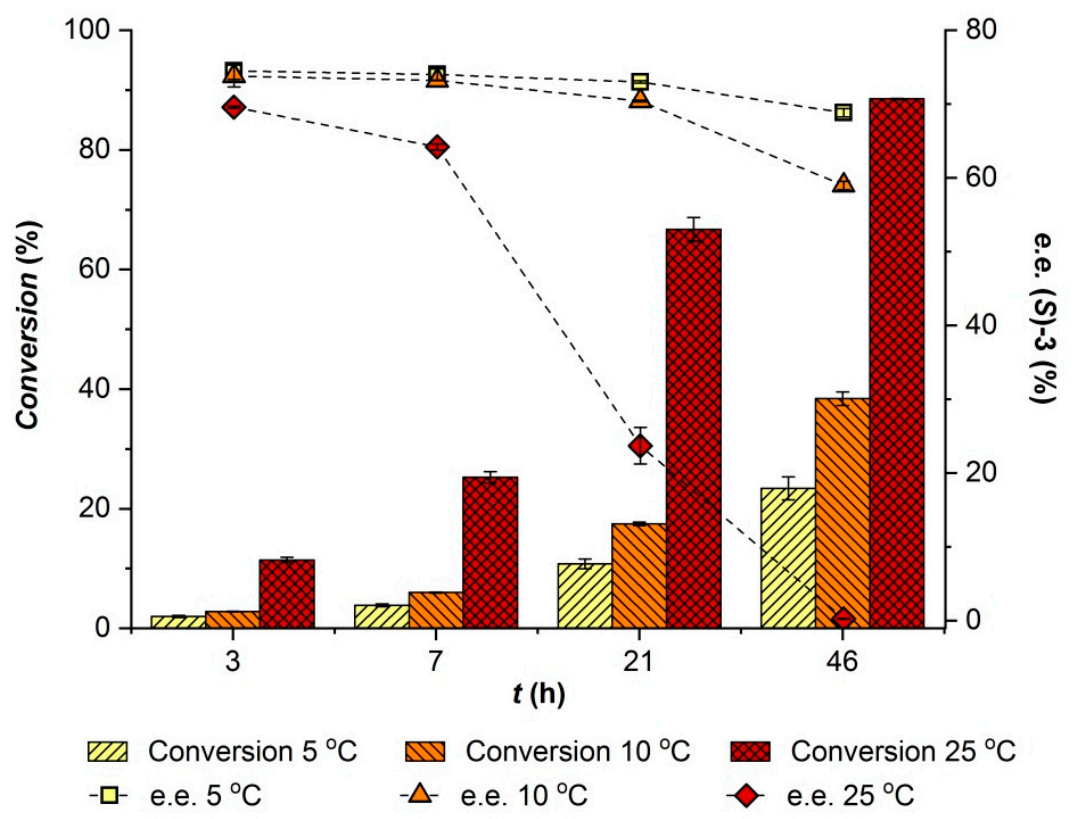

Figure 2. Effect of temperature on CALA-catalyzed benzoylation of $65 \mathrm{mM}( \pm)$-4-methoxymandelonitrile using $200 \mathrm{mM}$ phenyl benzoate.

\subsection{Selection of Enzyme Carriers}

In our designed cascade, we envisioned a low-water organic solvent system for which the immobilization of both enzymes would be required. In organic solvents, free lipases generally express low catalytic activity and they tend to form aggregates which can lead to mass transfer limitations [39]. Adsorption is believed to enhance the catalytic activity of lipases due to hydrophobic interactions between the support and part of the enzyme yielding the active enzyme conformation by opening the lid [40]. Similarly, immobilization of hydroxynitrile lyases can improve their activity and stability towards organic solvents [41], and may lead to higher enantioselectivity [42]. In this study, CALA was adsorbed on Relizyme EXE309, a macroporous bead based on a methyl methacrylate/styrene copolymer that was recommended by the manufacturer for effective lipase adsorption. For $\mathrm{MeHNL}$, adsorption on Celite R-633 was identified as the best immobilization method (see supporting information Table S2).

\subsection{Influence of Water Activity}

When working with enzymes in organic solvents, their activity is greatly affected by the water content in the reaction medium. This variable is best quantified in terms of thermodynamic water activity $\left(\mathrm{a}_{\mathrm{w}}\right)$, which is equal in all phases in equilibrium [43]. Water is believed to act as a molecular lubricant, increasing the conformational flexibility of enzymes and, thus, their catalytic activity [44]. The water content also affects enzyme selectivity in a complex way, which involves interactions with the reaction medium and the substrates [14].

In the case of HNLs it has been shown that when working at low water activities, the enzymes are insufficiently hydrated, resulting in activity and selectivity loss [12-14]. Lipases, on the other hand, can generally withstand lower water content [45], and some studies have shown that $a_{w}$ does 
not significantly influence the enantioselectivity of lipases [14,45-47]. Furthermore, water competes with the substrate alcohol (in this case, cyanohydrin) for the nucleophilic attack of the acyl-enzyme intermediate, leading to ester hydrolysis [48].

A prerequisite for the combination of both enzymes in a concurrent mode is to find a suitable $\mathrm{a}_{\mathrm{w}}$ range that allows for sufficient $\mathrm{MeHNL}$ activity and high selectivity, while minimizing ester hydrolysis catalyzed by CALA. In order to evaluate the $a_{w}$ effect on both enzymatic reactions, a salt hydrate system that could cover a wide range of $\mathrm{a}_{\mathrm{w}}$ values was selected: $\mathrm{Na}_{2} \mathrm{HPO}_{4} / \mathrm{Na}_{2} \mathrm{HPO}_{4} \cdot 2 \mathrm{H}_{2} \mathrm{O} / \mathrm{Na}_{2} \mathrm{HPO}_{4} \cdot 7 \mathrm{H}_{2} \mathrm{O} / \mathrm{Na}_{2} \mathrm{HPO}_{4} \cdot 12 \mathrm{H}_{2} \mathrm{O}$. These salt pairs afford water activity values of $0.15,0.57$ and 0.74 , respectively, at $20^{\circ} \mathrm{C}$ [43]. The hydrocyanation and benzoylation reactions were studied independently using immobilized $\mathrm{MeHNL}$ and CALA and the three salt pairs.

Before evaluating the influence of $\mathrm{a}_{\mathrm{w}}$ on $\mathrm{MeHNL}$, the effect of the phosphate salt hydrate pairs on the background hydrocyanation reaction was studied. The chemical hydrocyanation of $100 \mathrm{mM}$ 4-anisaldehyde in isopropyl ether was performed using 6.5 equivalents of $\mathrm{HCN}$ and $0.5 \mathrm{mmol}$ salt pair per $\mathrm{mL}$ of reaction. This revealed that the $\mathrm{Na}_{2} \mathrm{HPO}_{4} / \mathrm{Na}_{2} \mathrm{HPO}_{4} \cdot 2 \mathrm{H}_{2} \mathrm{O}$ pair could convert $32 \%$ of the aldehyde in $24 \mathrm{~h}$, whereas the other two salt pairs afforded a much lower chemical background reaction rate with only $4 \%$ conversion after $24 \mathrm{~h}$. The negative control, where no salt was added, showed $1 \%$ conversion.

The effect of the three water activity values provided by the phosphate salts on the $\mathrm{MeHNL}$-catalyzed hydrocyanation of 4-anisaldehyde was then evaluated (see Figure 3). Results at $\mathrm{a}_{\mathrm{w}}=0.15$ are difficult to interpret due to the above-mentioned catalytic effect of the salt. It seems, however, that the enzyme is hardly active at this low water activity. Comparison of the results at the two highest water activity values, where the background reaction is similarly low, shows that the activity and selectivity of $M e H N L$ increased with increasing $\mathrm{a}_{\mathrm{w}}$. Hence, to ensure a high e.e. of the resulting cyanohydrin, it is necessary to work at a high $\mathrm{a}_{\mathrm{w}}$ for the combination of $\mathrm{MeHNL}$ and CALA.

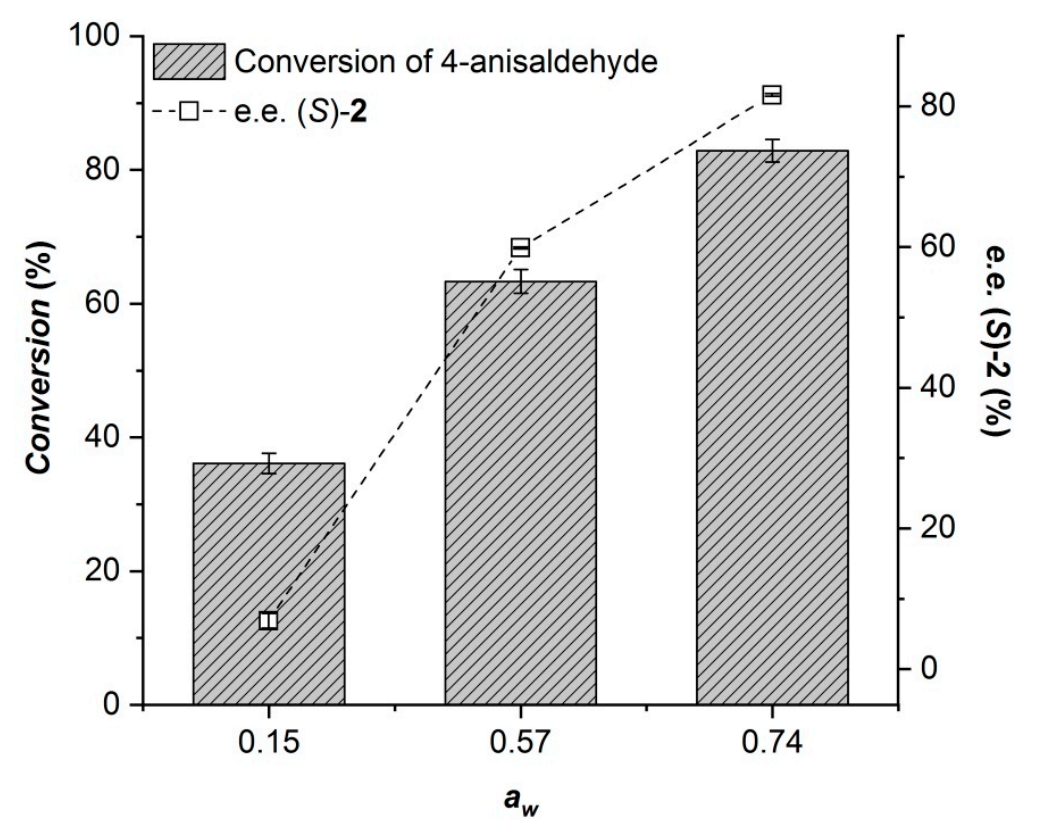

Figure 3. Effect of water activity on the $\mathrm{MeHNL}$-catalyzed hydrocyanation of $90 \mathrm{mM} 4$-anisaldehyde using 6.5 equivalents of $\mathrm{HCN}$. Conversion and enantiomeric excess (e.e.) values taken after $23 \mathrm{~h}$ of reaction.

In the case of CALA, at $\mathrm{a}_{\mathrm{w}}=0.57$ and below, no significant difference in the enantioselectivity of the enzyme $(E=5)$ or in the selectivity for transesterification over hydrolysis was observed (see Figure 4). When working at $\mathrm{a}_{\mathrm{w}}=0.74$, however, the hydrolysis rate increased significantly at the expense of the transesterification reaction. Although the enantioselectivity also increased under these 
conditions $(E=9)$, it is not a sufficient improvement to compensate for the increased hydrolysis rate. Considering the observed effects of water activity on MeHNL and CALA, we concluded that it should be possible to combine both enzymatic reactions at $\mathrm{a}_{\mathrm{w}}=0.57$.

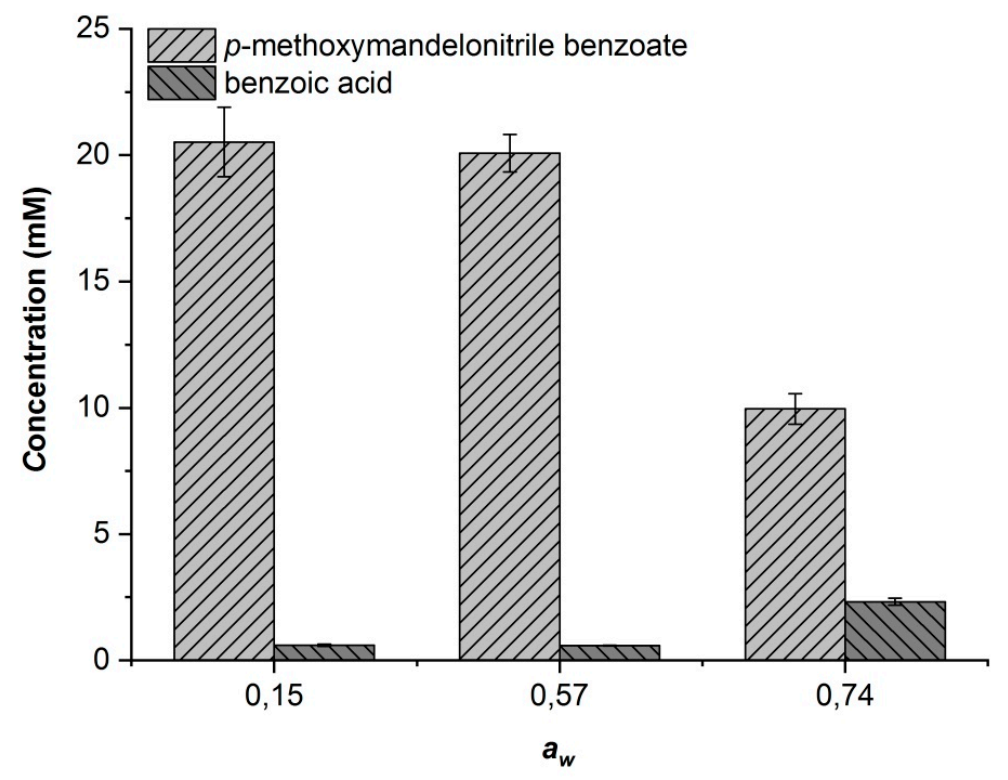

Figure 4. Effect of the different phosphate hydrate pairs on the CALA-catalyzed benzoylation of 66 $\mathrm{mM}( \pm)$-4-methoxymandelonitrile using $200 \mathrm{mM}$ vinyl benzoate after $22 \mathrm{~h}$ of reaction.

\subsection{Cross Interactions}

When performing reactions in one-pot, the reagents, products, or byproducts of one reaction may affect the other reactions. Thus, for an optimized cascade, the effect of hydrocyanation reagents on the CALA-catalyzed transesterification reaction as well as the influence of the benzoyl donor and the transesterification byproduct on the $\mathrm{MeHNL}$-catalyzed hydrocyanation reaction was evaluated. Further, the influence of the side product benzoic acid on both transesterification and hydrocyanation reactions was studied.

The influence of 4-anisaldehyde and $\mathrm{HCN}$ on the reaction rate and selectivity of the CALA-catalyzed benzoylation of 4-methoxymandelonitrile was evaluated. As shown in Figure 5A, both 4-anisaldehyde and $\mathrm{HCN}$ exert a moderate negative effect on the benzoylation rate. Moreover, both compounds reduce the selectivity of CALA towards transesterification (see Figure 5B). Regarding the enantioselectivity of the benzoylation reaction, it was not significantly affected by the presence of either of the hydrocyanation substrates, with the E values varying between 5 and 6 . Similarly, the effect of benzoic acid on CALA was studied in a benzoylation reaction of $70 \mathrm{mM}( \pm)-4$-methoxymandelonitirile containing one equivalent of benzoic acid. The reaction rate was $20 \%$ slower than that of the control.

The influence of phenyl benzoate and its leaving group, phenol, on the MeHNL-catalyzed hydrocyanation of 4-methoxymandelonitrile was studied. Addition of either three equivalents of phenyl benzoate or phenol to the hydrocyanation reaction afforded (S)-4-methoxymandelonitrile with the same yield and enantiopurity as the control reaction (data not shown). To evaluate the effect of the side product benzoic acid on the hydrocyanation reaction, an experiment was performed with addition of different amounts of the acid to the reaction mixture. As shown in Figure 6, benzoic acid exerts a strong negative effect on the hydrocyanation rate of $\mathrm{MeHNL}$. Thus, in order to achieve a cascade synthesis of $\mathbf{3}$ with high yield and selectivity, the CALA-catalyzed hydrolysis of phenyl benzoate and $\mathbf{3}$ should be minimized as much as possible. This observation is not surprising, since benzoic acid has previously been reported as a competitive inhibitor for other hydroxynitrile lyases [49-51]. Based on these results, the observed negative effect of benzoic acid on CALA is minor when compared to its effect on $\mathrm{MeHNL}$. 


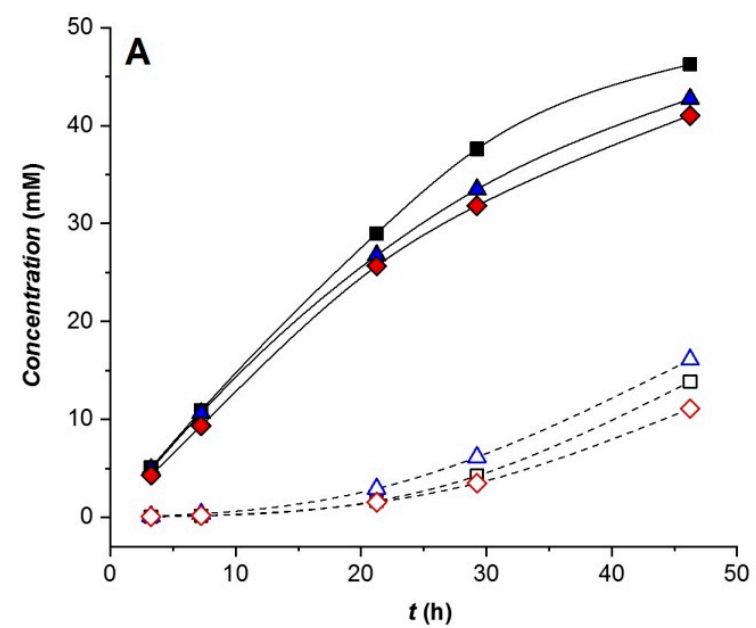

(S)-3 - positive control -- - - Benzoic acid - positive control $\Delta-(S)-3-\mathrm{HCN}$

$\checkmark(S)-3-p$-anisaldehyde

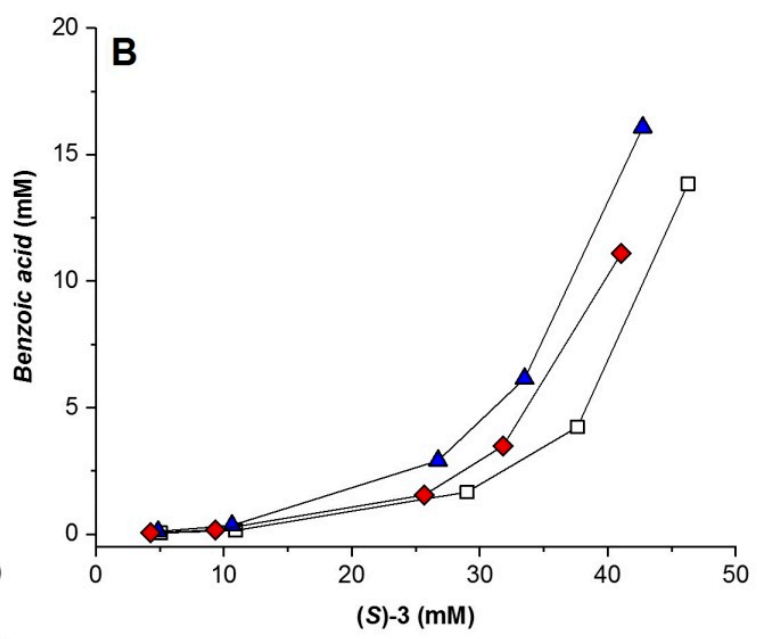

$\neg-$ Positive control $\neg-\mathrm{HCN} \backsim$-anisaldehyde

Figure 5. Effect of $60 \mathrm{mM} 4$-anisaldehyde and $209 \mathrm{mM} \mathrm{HCN}$ on the transesterification and hydrolysis rate of CALA (A) as well as its selectivity towards transesterification over hydrolysis (B) using $65 \mathrm{mM}$ ( \pm )-4-methoxymandelonitrile and $200 \mathrm{mM}$ phenyl benzoate.

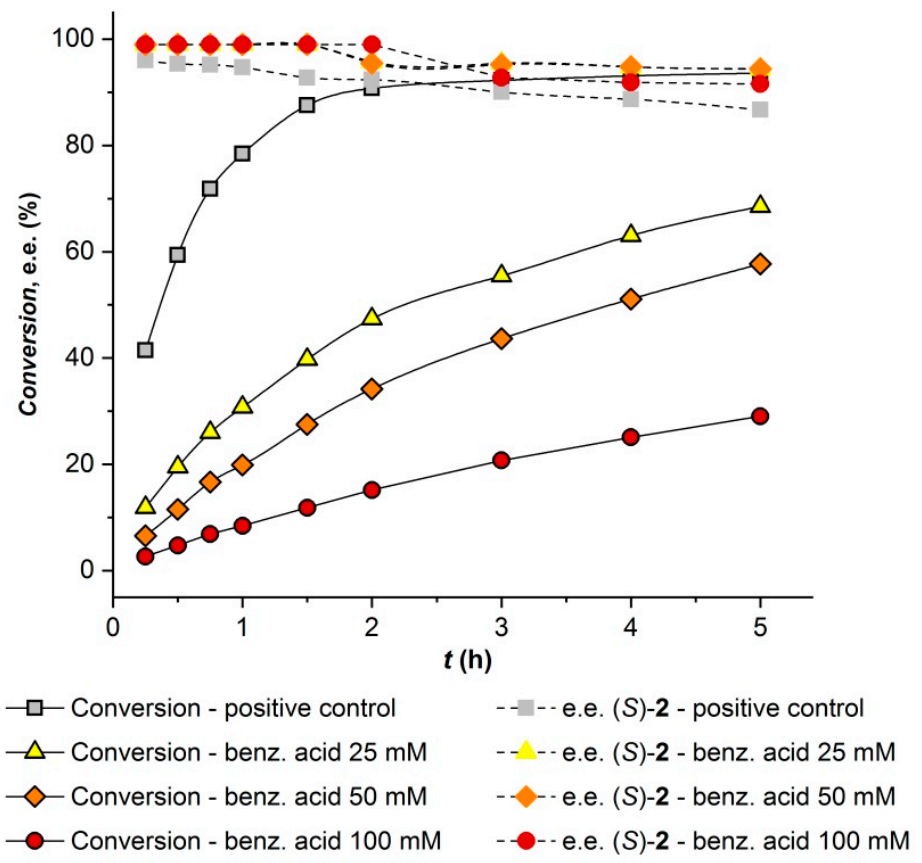

Figure 6. Effect of $25 \mathrm{mM}, 50 \mathrm{mM}$, or $100 \mathrm{mM}$ benzoic acid on MeHNL-catalyzed hydrocyanation of $100 \mathrm{mM} 4$-anisaldehyde using 6.5 equivalents of HCN. With exception of the positive control, the enantiomeric excess values overlap at low reaction times.

\subsection{Cascade Synthesis of (S)-4-Methoxymandelonitrile Benzoate}

For the first cascade synthesis test (see Table 1, entry 1), the used reaction conditions in terms of enzyme amount, temperature, water buffering salts and the time point of CALA addition were selected based on the results obtained before. The reaction temperature was set at $10{ }^{\circ} \mathrm{C}$, $\mathrm{Na}_{2} \mathrm{HPO}_{4} \cdot 2 \mathrm{H}_{2} \mathrm{O} / \mathrm{Na}_{2} \mathrm{HPO}_{4} \cdot 7 \mathrm{H}_{2} \mathrm{O}$ was added to set the water activity to $\mathrm{a}_{\mathrm{w}}=0.57$, and the lipase was added after $16 \mathrm{~h}$ of hydrocyanation reaction with the idea to minimize the exposure of $M e \mathrm{HNL}$ to benzoic acid. In this first reaction, a low reaction rate of the overall process was observed, resulting in only $10.5 \%$ conversion to the corresponding ester with a fair e.e. of $89 \%$ after $47 \mathrm{~h}$ reaction time. 
The results, however, showed that both enzymes were simultaneously active after adding the lipase to the reaction mixture, since the 4-anisaldehyde was further converted and (S)-4-methoxymandelonitrile benzoate was also formed. The same process was repeated at $25^{\circ} \mathrm{C}$ (Table 1 , entry 2 ) resulting in a significantly improved reaction rate, while maintaining the enantiomeric excess of the ester. Based on these observations, all further reactions were performed at room temperature $\left(20^{\circ} \mathrm{C}\right)$.

For comparison, in experiment 3 (Table 1, entry 3 ) a concurrent approach, where both enzymes were added from the beginning, was tested. Due to the inhibitory effect of 4 -anisaldehyde and HCN on the acyltransferase activity of CALA, a higher amount of lipase was added. This approach significantly improved the enantiopurity of the final ester ( $97 \%$ e.e.), while maintaining a good reaction rate. After $30.5 \mathrm{~h}$ of reaction, $10 \mathrm{mM}$ cyanohydrin was still present in the reaction mixture. This suggested that the transesterification rate was not too high in comparison to the MeHNL-catalyzed hydrocyanation. Therefore, it was decided to maintain the CALA/MeHNL ratio for further reactions. Strikingly, the results could be further improved by omitting the water buffering salts from the system (Table 1, entry 4). Elimination of these salts provided overall higher yield and selectivity, which may be explained by the previously identified negative effect of low water activity on the enzymatic hydrocyanation reaction. Moreover, comparison of the benzoic acid concentration in experiments 3 and 4 indicated that in the former cascade (including the salts) the hydrolysis reaction was not suppressed to a higher extent than in the latter (without salts). Thus, the use of the salt hydrate pair did not further reduce the hydrolysis reaction in the studied system.

Salt-free experiments with varying initial amounts of benzoyl donor (Table 1, entries 4-6) showed a detrimental effect of higher donor concentrations on the hydrocyanation reaction, while the amount of hydrolysis side product, benzoic acid, increased substantially. In all cases, however, excellent enantiopurity of (S)-4-methoxymandelonitrile benzoate (99\% e.e.) was maintained throughout the process. These results prompted us to test gradual addition of phenyl benzoate to the process, which was found to minimize the hydrolytic side reaction at the expense of some loss in reaction rate (see Table 1, entry 7), leading to $64 \%$ yield of ester 3 (98\% e.e.) in 49 h, with $50 \%$ less benzoic acid produced compared to Table 1, entry 5. Finally, we hypothesized that a reduction of the lipase units could further decrease the amount of formed benzoic acid. Using $0.5 \mathrm{U} / \mathrm{ml}$ CALA afforded ester 3 (98\% e.e.) with $81 \%$ yield in $122 \mathrm{~h}$, with a total conversion of 4 -anisaldehyde of $95 \%$ (see Table 1 , entry 8 and Figure S3). The reaction time required for high conversion values could be reduced by approximately one day when the reaction temperature was increased from 20 to $25^{\circ} \mathrm{C}$ (see Table 1, entry 10).

Furthermore, we also tested the possibility of decreasing the amount of $\mathrm{HCN}$ used in the cascade. However, when performing the cascade using 5 instead of 6.5 equivalents of HCN (using the same conditions detailed in Table 1, entry 7), after $122 \mathrm{~h}$ only $60 \mathrm{mM}(S)-3$ was produced with a poor enantiomeric excess of $87 \%$. Similarly, a decrease in yield and enantiomeric excess of (S)-2 was observed in the immobilized MeHNL-catalyzed hydrocyanation of 4-anisaldehyde when decreasing the HCN concentration (see Figure S4).

Overall, our results demonstrate that the concurrent combination of a MeHNL-catalyzed hydrocyanation with a CALA-catalyzed transesterification is possible after careful investigation of the individual reactions in search for compatible conditions. However, further optimization is required to improve the cascade, since $5 \%$ residual 4 -anisaldehyde could not be converted by $\mathrm{MeHNL}$ (see Table 1, entry 8 and Figure S4A). Presumably, this is due to an observed increase in benzoic acid concentration as the cascade proceeds. Moreover, roughly $11 \mathrm{mM}$ cyanohydrin 2 remained in the reaction media, which could not be further converted to 3 by CALA. This indicates a rather low affinity of the lipase for 4-methoxymandelonitrile, which, at low concentrations, cannot compete with the water present in the reaction medium for the acyl-enzyme complex. Hence, hydrolysis is the main reaction taking place in the end, further increasing the amount of benzoic acid.

The use of an engineered CALA with enhanced selectivity towards transesterification reactions versus hydrolysis could significantly improve the performance of our designed cascade [29]. 
Table 1. Cascade synthesis of (S)-4-methoxymandelonitrile benzoate catalyzed by immobilized MeHNL and CALA starting from $100 \mathrm{mM} 4$-anisaldehyde and $650 \mathrm{mM}$ HCN using 200-400 mM phenyl benzoate. Reactions were performed in duplicate and relative standard deviations were generally below $2 \%$.

\begin{tabular}{|c|c|c|c|c|c|c|c|c|c|c|c|}
\hline Exp. & $\mathrm{T}\left({ }^{\circ} \mathrm{C}\right)$ & $\begin{array}{c}\text { Equiv. Phenyl } \\
\text { Benzoate }\end{array}$ & $\begin{array}{l}\text { MeHNL } \\
(\mathrm{U} / \mathrm{mL})^{1}\end{array}$ & $\begin{array}{c}\text { CALA } \\
(\mathrm{U} / \mathrm{mL})^{2}\end{array}$ & Time (h) & [1] (mM) & [2] (mM) & $\begin{array}{c}\text { e.e. }(S)-2 \\
(\%)\end{array}$ & [3] (mM) & $\begin{array}{c}\text { e.e. }(S)-3 \\
(\%)\end{array}$ & $\begin{array}{c}\text { [benzoic } \\
\text { acid] }(\mathbf{m M})\end{array}$ \\
\hline \multirow{2}{*}{$1^{3}$} & \multirow{2}{*}{10} & \multirow{2}{*}{3} & \multirow{2}{*}{0.21} & \multirow{2}{*}{$0.50^{4}$} & 16 & 90 & 10 & 58 & - & - & - \\
\hline & & & & & 47 & 82 & 7 & 12 & 11 & 89 & ND \\
\hline \multirow{2}{*}{$2^{3}$} & \multirow{2}{*}{25} & \multirow[b]{2}{*}{3} & \multirow{2}{*}{0.21} & \multirow{2}{*}{$0.50^{5}$} & 15 & 75 & 25 & 63 & - & - & - \\
\hline & & & & & 24 & 59 & 11 & 15 & 30 & 90 & ND \\
\hline $3^{3}$ & 20 & 2 & 0.26 & 2.20 & 31 & 47 & 10 & 70 & 43 & 97 & 64 \\
\hline \multirow{2}{*}{4} & \multirow{2}{*}{20} & \multirow{2}{*}{2} & \multirow{2}{*}{0.26} & \multirow{2}{*}{2.20} & 31 & 23 & 21 & 92 & 56 & 99 & 57 \\
\hline & & & & & 73 & 15 & 23 & 86 & 62 & 98 & 111 \\
\hline 5 & 20 & 3 & 0.26 & 2.20 & 31 & 33 & 8 & 76 & 59 & 99 & 109 \\
\hline 6 & 20 & 4 & 0.26 & 2.20 & 31 & 45 & 4 & 68 & 51 & 99 & 140 \\
\hline \multirow{2}{*}{7} & \multirow{2}{*}{20} & \multirow{2}{*}{$3^{6}$} & \multirow{2}{*}{0.26} & \multirow{2}{*}{2.20} & 49 & 18 & 19 & 74 & 64 & 98 & 56 \\
\hline & & & & & 122 & 15 & 13 & 79 & 72 & 93 & 210 \\
\hline \multirow{2}{*}{8} & \multirow{2}{*}{20} & \multirow{2}{*}{$3^{6}$} & \multirow{2}{*}{0.26} & \multirow{2}{*}{0.50} & 122 & 5 & 14 & 60 & 81 & 98 & 50 \\
\hline & & & & & 164 & 4 & 11 & 61 & 85 & 96 & 94 \\
\hline 9 & 20 & 0 & 0.26 & 0 & 24 & 15 & 85 & 91 & - & - & - \\
\hline 10 & 25 & $3^{3}$ & 0.26 & 0.50 & 94 & 7 & 13 & 46 & 80 & 97 & 39 \\
\hline
\end{tabular}

${ }^{1}$ Activity of immobilized MeHNL: $0.03 \mathrm{U} / \mathrm{mg} .{ }^{2}$ Activity of immobilized CALA: $0.11 \mathrm{U} / \mathrm{mg} .{ }^{3} \mathrm{Na}_{2} \mathrm{HPO}_{4} \cdot 2 \mathrm{H}_{2} \mathrm{O} / \mathrm{Na}_{2} \mathrm{HPO}_{4} \cdot 7 \mathrm{H}_{2} \mathrm{O}$ was added $\left(0.34 \mathrm{mmol}\right.$ per mL of reaction). ${ }^{4} \mathrm{CALA}$ was added after $16 \mathrm{~h} .{ }^{5} \mathrm{CALA}$ was added after $15 \mathrm{~h} .{ }^{6}$ Gradual addition: Each 1 equivalent of phenyl benzoate was added at the beginning, after $24 \mathrm{~h}$, and after $48 \mathrm{~h}$. 


\section{Materials and Methods}

\subsection{Enzymes}

Hydroxynitrile lyase from Manihot esculenta was heterologously expressed in E. coli K12 Top 10F' harboring the pSE420-MeHNL plasmid, which was kindly provided by Dr. Kerstin Steiner from the Austrian Centre of Industrial Biotechnology (ACIB). $2 \times$ YT medium $(100 \mathrm{~mL}$, containing $100 \mu \mathrm{g} / \mathrm{mL}$ ampicillin) was inoculated from a glycerol stock $(10 \mu \mathrm{L})$ and the culture was incubated overnight at $37^{\circ} \mathrm{C}, 200 \mathrm{rpm}$. A $5 \mathrm{~mL}$ aliquot of this preculture $\left(\mathrm{OD}_{600}=4.4\right)$ was used to inoculate $2 \times \mathrm{YT}$ medium (500 mL, containing $100 \mu \mathrm{g} / \mathrm{mL}$ ampicillin), and the new culture was grown at $37^{\circ} \mathrm{C}, 200 \mathrm{rpm}$. At an optical density at $600 \mathrm{~nm}\left(\mathrm{OD}_{600}\right)$ of 0.8 , IPTG was added to a final concentration of $0.1 \mathrm{mM}$ and the culture was further incubated at $18{ }^{\circ} \mathrm{C}, 160 \mathrm{rpm}$ for $48 \mathrm{~h}$. Cells were harvested by centrifugation at $4000 \mathrm{~g}, 4^{\circ} \mathrm{C}$ for $10 \mathrm{~min}$, washed with $25 \mathrm{mM}$ sodium acetate buffer, $\mathrm{pH} 5.8$, and centrifuged again ( $4000 \mathrm{~g}, 4{ }^{\circ} \mathrm{C}$ for $30 \mathrm{~min}$ ). Cell pellets were resuspended in $25 \mathrm{mM}$ sodium acetate, pH 5.8 (4 mL per $\mathrm{g}$ of wet cells), and $10 \mathrm{~mL}$ aliquots were sonicated at $4{ }^{\circ} \mathrm{C}$ using a Fisher Scientific Model 120 Sonic Dismembrator at $60 \%$ amplitude, $2 \mathrm{~s}$ pulse, $5 \mathrm{~s}$ pause for $7 \mathrm{~min}$. The resulting crude extract was centrifuged to remove cell debris $\left(18,500 \mathrm{~g}, 4^{\circ} \mathrm{C}\right.$ for $\left.45 \mathrm{~min}\right)$ and the obtained cell free extract was stored at $-20^{\circ} \mathrm{C}$. Concentration of cell free extract was performed in an Amicon Ultra Filter Device with $10 \mathrm{kDa}$ cut-off at $4{ }^{\circ} \mathrm{C}$.

Candida antarctica lipase A (Novozym®CALA L, LDN 00025) was purchased from Novozymes.

\subsubsection{Enzyme Activity Measurements}

The enzymatic activity of free $M e H N L$ was measured following the cleavage of racemic mandelonitrile into benzaldehyde and $\mathrm{HCN}$, according to a literature procedure [52]. Samples were prepared by diluting the $\mathrm{MeHNL}$ cell free extract in $5 \mathrm{mM}$ phosphate buffer, $\mathrm{pH}$ 6.5. The enzymatic activity of immobilized $\mathrm{MeHNL}$ was determined following the hydrocyanation of 4-anisaldehyde $(100 \mathrm{mM})$ using 6.5 equivalents of $\mathrm{HCN}$ in isopropyl ether at $20^{\circ} \mathrm{C}, 800 \mathrm{rpm}$. A negative control was performed using the enzyme support instead. Samples were analyzed by chiral HPLC.

The enzymatic activity of CALA was measured according to a modified literature procedure following the hydrolysis of tributyrin in phosphate buffer at $\mathrm{pH} 7$ [53]. The resulting butyric acid was titrated with $0.1 \mathrm{M}$ sodium hydroxide, and the consumption of the latter was recorded as a function of time. The enzymatic activity of immobilized CALA was determined following the hydrolysis of 4-nitrophenyl butyrate $(1.67 \mathrm{mM})$ in acetonitrile/50 $\mathrm{mM}$ phosphate $\mathrm{pH} 7.4(1 / 5)$. A calibration curve of the product 4-nitrophenol was used to calculate the reaction rate based on the absorbance of the reaction mixture at $410 \mathrm{~nm}$.

\subsubsection{Enzyme Immobilization}

General procedure for $M e H N L$ : In a $5 \mathrm{~mL}$ glass vial containing a magnetic stirring bar and the carrier $(100 \mathrm{mg}), \mathrm{MeHNL}-\mathrm{containing}$ cell-free extract $(40 \mu \mathrm{L})$ was added dropwise while stirring. The mixture was stirred for $30 \mathrm{~min}$ and was then dried at room temperature under high vacuum for $48 \mathrm{~h}$.

Immobilization of CALA: CALA (30 g), Relizyme EXE309 (30 g), and demineralized water (30 mL) were mixed in a $100 \mathrm{~mL}$ bottle. The $\mathrm{pH}$ was adjusted to 6 with a solution of $2 \mathrm{M}$ sodium hydroxide and the mixture was incubated at room temperature in an orbital shaker overnight. After filtering the solution, the activity of the supernatant was measured and compared to the initial activity of the enzyme solution before immobilization, giving an immobilization yield of $84 \%$. The immobilized enzyme was washed several times with demineralized water and dried at room temperature under high vacuum for $48 \mathrm{~h}$. 


\subsubsection{Evaluation of the MeHNL Immobilisates}

To $1.5 \mathrm{~mL}$ glass vials containing different $\mathrm{MeHNL}$ immobilisates $(15 \mathrm{mg})$ and $\mathrm{Na}_{2} \mathrm{HPO}_{4} \cdot 2 \mathrm{H}_{2} \mathrm{O}$ (30 mg, $0.17 \mathrm{mmol}$ ), each a solution of $100 \mathrm{mM} 4$-anisaldehyde and $650 \mathrm{mM} \mathrm{HCN}$ in isopropyl ether $(500 \mu \mathrm{L})$ was added. Duplicate reactions per immobilisate were incubated at $20^{\circ} \mathrm{C}$ in an orbital shaker at $800 \mathrm{rpm}$. Samples $(20 \mu \mathrm{L})$ were analyzed by HPLC.

\subsection{Chemicals}

Unless otherwise indicated, reagents and organic solvents were purchased from Fisher Scientific, Sigma-Aldrich, TCI Chemicals and Acros Organics, and were of the highest available purity.

Celite R633 was a gift from Imerys S.A., Relizyme EXE309 was kindly provided by Resindion S.r.l., and SYLOID silicas were a gift from Grace Davison, Inc. ( \pm )-4-Methoxymandelonitrile was synthetized via chemical hydrocyanation of 4-anisaldehyde following a literature procedure [22].

For the preparation of hydrogen cyanide solution, potassium cyanide $(26 \mathrm{~g}, 0.4 \mathrm{~mol})$ was dissolved in a stirred mixture of distilled water $(200 \mathrm{~mL})$ and diisopropyl ether $\left({ }^{\mathrm{i}} \mathrm{Pr}_{2} \mathrm{O}\right)(100 \mathrm{~mL})$. The solution was cooled in an ice-water bath and $1.33 \mathrm{M}$ citric acid ( $100 \mathrm{~mL}, 0.13 \mathrm{~mol}, 1$ equivalent) was slowly added. The aqueous layer was extracted twice with $50 \mathrm{~mL}$ of ${ }^{i} \mathrm{Pr}_{2} \mathrm{O}$. The combined organic phases were stored in a dark bottle containing $1 \mathrm{M}$ citrate buffer $\mathrm{pH} 5.5(10 \mathrm{~mL})$. The HCN concentration was determined by measuring the absorption of the $\left[\mathrm{Ni}(\mathrm{CN})_{4}\right]^{2-}$ complex ion at $267 \mathrm{~nm}$. HCN solution $(20 \mu \mathrm{L})$ was added to $3.5 \mathrm{mM} \mathrm{NiSO} \cdot 6 \mathrm{H}_{2} \mathrm{O}$ in $1 \mathrm{M} \mathrm{NH}_{3}(4 \mathrm{~mL})$ [54]. After vigorous mixing, the solution was further diluted 50 times with $1 \mathrm{M} \mathrm{NH}_{3}$ in a cuvette. The absorption was measured and the resulting $\mathrm{HCN}$ concentration was calculated based on a calibration curve.

Synthesis of ( \pm )-4-Methoxymandelonitrile (2)

In a $100 \mathrm{~mL}$ round-bottom flask, $\mathrm{NaCN}(4.4 \mathrm{~g}, 90 \mathrm{mmol})$ was dissolved in water $(30 \mathrm{~mL})$ and $\mathrm{NaHSO}_{3}(9.4 \mathrm{~g}, 90 \mathrm{mmol})$ was slowly added. 4-Anisaldehyde $(2.4 \mathrm{~g}, 18 \mathrm{mmol})$ was dissolved in ethyl acetate $(20 \mathrm{~mL})$ and added to the reaction mixture. After $1 \mathrm{~h}$ of vigorous stirring, the flask was introduced in an ice-water bath and stirred for another $6 \mathrm{~h}$. The reaction was followed by HPLC until it reached plateau after $90 \%$ conversion. Distilled water $(30 \mathrm{~mL})$ was added to dissolve the salts and the aqueous phase was extracted ethyl acetate $(2 \times 10 \mathrm{~mL})$. The combined organic phase was washed with brine, dried over anhydrous $\mathrm{MgSO}_{4}$, and concentrated on a rotary evaporator using a $10^{\circ} \mathrm{C}$ bath, whereupon crystallization occurred. The crystals were washed with cold heptane/ethyl acetate (2:1) and stored at $5{ }^{\circ} \mathrm{C}$. HPLC analysis showed that the $( \pm)$-4-methoxymandelonitrile crystals contained $3 \%$ 4-anisaldehyde impurity.

\subsection{Bioconversions}

All bioconversions were performed in $1.5 \mathrm{~mL}$ glass vials in an orbital shaker at $800 \mathrm{rpm}$. Unless otherwise stated, the reaction temperature was set at $20^{\circ} \mathrm{C}$.

\subsubsection{Benzoyl Donor Screening}

To a vial containing immobilized CALA ( $4.2 \mathrm{mg}, 0.46 \mathrm{U})$, racemic 4-methoxymandelonitrile $(200 \mathrm{mM})$ in isopropyl ether $(250 \mu \mathrm{L})$ and benzoyl donor $(300 \mathrm{mM})$ in isopropyl ether $(500 \mu \mathrm{L})$ was added. Reactions were performed in duplicate and were incubated at $25^{\circ} \mathrm{C}$. Samples $(20 \mu \mathrm{L})$ were taken after 4,20 , and $27.5 \mathrm{~h}$ and analyzed by HPLC. The enantioselectivity was calculated according to the method of Chen et al. for conversion values between 5 and 20\% [55].

\subsubsection{Temperature Effect on $M e \mathrm{HNL}$}

4-Anisaldehyde $(530 \mathrm{mM})$ in isopropyl ether $(188 \mu \mathrm{L}), \mathrm{HCN}(800 \mathrm{mM})$ in isopropyl ether $(812 \mu \mathrm{L})$, citrate buffer $\mathrm{pH} 5(500 \mathrm{mM}, 125 \mu \mathrm{L})$, and $\mathrm{MeHNL}$-containing cell-free extract ( $33.2 \mu \mathrm{L}, 5 \mathrm{U})$ were incubated at 5,10 , and $20^{\circ} \mathrm{C}$. Reactions were performed in duplicate and a negative control reaction 
was performed for each temperature value, where no enzyme was added. Samples $(20 \mu \mathrm{L})$ were taken from the upper organic phase after 6,22 , and $75 \mathrm{~h}$ and analyzed by HPLC.

\subsubsection{Temperature Effect on CALA}

To a vial containing CALA ( $2 \mathrm{mg}, 0.22 \mathrm{U}),( \pm)-4$-methoxymandelonitrile $(195 \mathrm{mM})$ in isopropyl ether $(125 \mu \mathrm{L})$ and phenyl benzoate $(300 \mathrm{mM})$ in isopropyl ether $(250 \mu \mathrm{L})$ was added. The mixture was incubated at 5,10 , and $25^{\circ} \mathrm{C}$. Reactions were performed in duplicate. Samples $(20 \mu \mathrm{L})$ were taken after $3,7,21$, and $46 \mathrm{~h}$ and analyzed by HPLC.

\subsubsection{Effect of $\mathrm{Na}_{2} \mathrm{HPO}_{4}$ Salt Hydrates on Chemical Hydrocyanation}

To a solution of 4-anisaldehyde $(100 \mathrm{mM})$ and $\mathrm{HCN}(650 \mathrm{mM})$ in isopropyl ether $(1 \mathrm{~mL})$, anhydrous $\mathrm{Na}_{2} \mathrm{HPO}_{4}(70 \mathrm{mg}, 0.5 \mathrm{mmol}), \mathrm{Na}_{2} \mathrm{HPO}_{4} \cdot 2 \mathrm{H}_{2} \mathrm{O}(85 \mathrm{mg}, 0.5 \mathrm{mmol})$, or $\mathrm{Na}_{2} \mathrm{HPO}_{4} \cdot 7 \mathrm{H}_{2} \mathrm{O}(134 \mathrm{mg}, 0.5 \mathrm{mmol})$ was added. Reactions were performed in duplicate and a control reaction without salt was run in parallel. The amount of salt added is based on the maximum solubility of water in isopropyl ether $(0.55 \mathrm{wt} \%)$ [56] and the water capacity of the $\mathrm{Na}_{2} \mathrm{HPO}_{4} / \mathrm{Na}_{2} \mathrm{HPO}_{4} \cdot 2 \mathrm{H}_{2} \mathrm{O}$ salt pair $(11.2 \mathrm{mmol} / \mathrm{g})$ [57]. Reactions were stopped after $24 \mathrm{~h}$ and analyzed by HPLC.

\subsubsection{Effect of $\mathrm{a}_{\mathrm{w}}$ on $\mathrm{MeHNL}$}

To a vial containing MeHNL immobilized on Celite R633 (12 mg, $0.36 \mathrm{U})$, a solution of 4-anisaldehyde $(90 \mathrm{mM})$ and $\mathrm{HCN}(590 \mathrm{mM})$ in isopropyl ether $(550 \mu \mathrm{L})$ was added, together with either anhydrous $\mathrm{Na}_{2} \mathrm{HPO}_{4}(35 \mathrm{mg}, 0.25 \mathrm{mmol}), \mathrm{Na}_{2} \mathrm{HPO}_{4} \cdot 2 \mathrm{H}_{2} \mathrm{O}(42 \mathrm{mg}, 0.25 \mathrm{mmol})$ or $\mathrm{Na}_{2} \mathrm{HPO}_{4} \cdot 7 \mathrm{H}_{2} \mathrm{O}$ $(67 \mathrm{mg}, 0.25 \mathrm{mmol})$. Reactions were performed in duplicate. Samples $(20 \mu \mathrm{L})$ were taken after 5 and $24 \mathrm{~h}$ and analyzed by HPLC.

\subsubsection{Effect of $\mathrm{a}_{\mathrm{w}}$ on CALA}

To a vial containing CALA immobilized on Relizyme EXE309 (4 mg, $0.44 \mathrm{U}$ ), a solution of $( \pm)$-4-methoxymandelonitrile $(100 \mathrm{mM})$ and vinyl benzoate $(300 \mathrm{mM})$ in isopropyl ether $(500 \mu \mathrm{L})$ was added, together with either anhydrous $\mathrm{Na}_{2} \mathrm{HPO}_{4}(35 \mathrm{mg}, 0.25 \mathrm{mmol}), \mathrm{Na}_{2} \mathrm{HPO}_{4} \cdot 2 \mathrm{H}_{2} \mathrm{O}(42 \mathrm{mg}$, $0.25 \mathrm{mmol})$, or $\mathrm{Na}_{2} \mathrm{HPO}_{4} \cdot 7 \mathrm{H}_{2} \mathrm{O}(67 \mathrm{mg}, 0.25 \mathrm{mmol})$. Samples $(20 \mu \mathrm{L})$ were taken after 6,22 , and $30 \mathrm{~h}$ and analyzed by HPLC.

\subsubsection{Effect of Phenol and Phenyl Benzoate on MeHNL}

To a solution of 4-anisaldehyde $(100 \mathrm{mM})$ and $\mathrm{HCN}(600 \mathrm{mM})$ in isopropyl ether $(670 \mu \mathrm{L}), \mathrm{MeHNL}$ on Celite R633 (8 mg, $0.24 \mathrm{U}$ ) and either phenol (18.8 mg, $200 \mu \mathrm{mol})$ or phenyl benzoate (39.6 mg, $200 \mu \mathrm{mol})$ were added. A control was performed without addition of phenol or phenyl benzoate. Samples $(20 \mu \mathrm{L})$ were taken after 17 and $22 \mathrm{~h}$ and analyzed by HPLC.

\subsubsection{Effect of 4-Anisaldehyde and HCN on CALA}

To a solution of $( \pm)$-4-methoxymandelonitrile $(65 \mathrm{mM})$ and phenyl benzoate $(200 \mathrm{mM})$ in isopropyl ether $(375 \mu \mathrm{L})$, CALA on Relizyme EXE309 (2 mg, $0.22 \mathrm{U}$ ) and either 4-anisaldehyde (200 mM) in isopropyl ether $(160 \mu \mathrm{L})$ or HCN $(700 \mathrm{mM})$ in isopropyl ether $(160 \mu \mathrm{L})$ were added. Reactions were performed in duplicate and a control was performed adding isopropyl ether $(160 \mu \mathrm{L})$ instead of the hydrocyanation reagents. The reactions were incubated at $25^{\circ} \mathrm{C}$. Samples $(20 \mu \mathrm{L})$ were taken after 3,7 , 21, 29, and $46 \mathrm{~h}$ and analyzed by HPLC.

\subsubsection{Effect of Benzoic Acid on MeHNL}

To a vial containing $M e H N L$ on Celite R633 (15 mg, $0.45 \mathrm{U}$ ) and benzoic acid $(1.5 \mathrm{mg}, 12 \mu \mathrm{mol} ; 3 \mathrm{mg}$, $25 \mu \mathrm{mol}$; or $6 \mathrm{mg}, 50 \mu \mathrm{mol})$, a solution of 4-anisaldehyde $(100 \mathrm{mM}), \mathrm{HCN}(650 \mathrm{mM})$, and mesitylene 
$(100 \mathrm{mM})$ (internal standard) in isopropyl ether $(500 \mu \mathrm{L})$ was added. A control was performed without addition of benzoic acid. Samples $(20 \mu \mathrm{L})$ were analyzed by HPLC.

\subsubsection{Effect of Benzoic Acid on CALA}

To a solution of $( \pm)-4$-methoxymandelonitrile $(100 \mathrm{mM})$, phenyl benzoate $(300 \mathrm{mM})$ and mesitylene $(100 \mathrm{mM})$ (internal standard) in isopropyl ether $(350 \mu \mathrm{L})$, CALA on Relizyme EXE309 (2 mg, $0.22 \mathrm{U})$, and $\mathrm{Na}_{2} \mathrm{HPO}_{4} \cdot 2 \mathrm{H}_{2} \mathrm{O}(30 \mathrm{mg}, 0.17 \mathrm{mmol})$, benzoic acid $(70 \mathrm{mM})$ in isopropyl ether ( $150 \mu \mathrm{L}, 1$ equivalent) were added. A control was performed adding isopropyl ether $(150 \mu \mathrm{L})$ instead of benzoic acid solution. Samples $(20 \mu \mathrm{L})$ were analyzed by HPLC.

\subsubsection{General Procedure for the Cascade Synthesis of (S)-4-Methoxymandelonitrile Benzoate}

To a vial containing immobilized $\mathrm{MeHNL}$ and CALA, $\mathrm{Na}_{2} \mathrm{HPO}_{4} \cdot 2 \mathrm{H}_{2} \mathrm{O}(30 \mathrm{mg}$, for experiments 1-3, Table 1) was added. A solution of 4-anisaldehyde ( $360 \mathrm{mM})$ and mesitylene (360 $\mathrm{mM})$ (internal standard) in isopropyl ether $(140 \mu \mathrm{L})$ and $\mathrm{HCN}(900 \mathrm{mM})$ in isopropyl ether $(360 \mu \mathrm{L})$ was subsequently added. To this mixture, phenyl benzoate (2-4 equivalents) was added (in case of experiments 7 and 8 from Table 1, 1 equivalent was added each time at $\mathrm{t}=0$, after $24 \mathrm{~h}$ and after $46 \mathrm{~h}$ ) and the reactions were incubated at 10,20 , or $25^{\circ} \mathrm{C}$. Negative control reactions without enzyme addition were performed in parallel. Reactions were performed in duplicate and $20 \mu \mathrm{L}$ samples were analyzed by HPLC.

\subsection{HPLC Analysis}

The quantification of 4-anisaldehyde, $(S)$ - and $(R)-4$-methoxymandelonitrile and $(S)$ - and $(R)-4$-methoxymandelonitrile benzoate was achieved using chiral normal phase HPLC. Samples from reaction mixtures were diluted $50 \times$ with $n$-heptane/isopropanol 8:2 $\mathrm{v} / \mathrm{v}$ and dried over anhydrous magnesium sulfate. Analysis was performed using a Hitachi Elite LaChrom HPLC system, consisting of a VWR Hitachi L-2130 pump, L-2200 auto-sampler, L-2350 column oven, and L-2400 UV detector using a $\mathrm{D}_{2}$ lamp coupled to a Hitachi organizer module. Separation was achieved on a Chiralpak AD-H column (250 $\mathrm{mm} \times 4.6 \mathrm{~mm} \times 5 \mu \mathrm{m}$; Daicel, Japan), using n-heptane/isopropanol (82/18) at a flow rate of $0.65 \mathrm{~mL} / \mathrm{min}$. The column oven temperature was set at $35^{\circ} \mathrm{C}$ and a detection wavelength of $225 \mathrm{~nm}$ was chosen. Under these conditions, the compounds were separated with the following retention times; mesitylene (internal standard) $5.0 \mathrm{~min}$, benzoic acid $6.7 \mathrm{~min}$, phenol $7.0 \mathrm{~min}$, phenyl benzoate $7.3 \mathrm{~min}$, 4-anisaldehyde $8.3 \mathrm{~min},(S)$-4-methoxymandelonitrile $9.6 \mathrm{~min},(R)-4$-methoxymandelonitrile $10.5 \mathrm{~min},(S)-4$-methoxymandelonitrile benzoate $13.1 \mathrm{~min}$, and $(R)-4$-methoxymandelonitrile benzoate $13.9 \mathrm{~min}$.

Reverse-phase HPLC was used for the quantification of benzoic acid. Samples from reaction mixtures were diluted $50 \times$ with acetonitrile/water 1:1 v/v. Analysis was performed using a Shimadzu Nexera XR HPLC system equipped with a DGU-20A5R degassing unit, coupled to two LC-20AD solvent delivery units, a SIL-20AC Autosampler, a CTO-20A column oven, an SPD-20A UV/VIS detector using a $\mathrm{D}_{2}$ lamp, and a CBM-20A system controller. Separation was achieved on a Nucleoshell RP 18 column $\left(150 \mathrm{~mm} \times 3 \mathrm{~mm} \times 2.7 \mu \mathrm{m}\right.$; Macherey-Nagel, Germany) at $30^{\circ} \mathrm{C}, 0.7 \mathrm{~mL} / \mathrm{min}$ flow rate using MilliQßwater containing $0.1 \%$ trifluoroacetic acid (solvent A) and acetonitrile (solvent B) as mobile phase and UV detection at $225 \mathrm{~nm}$. The following eluent program was used; $10 \%$ solvent B for $0.5 \mathrm{~min}$, followed by a linear gradient to $45 \%$ solvent B in $5.5 \mathrm{~min}, 45 \%$ solvent B for $10 \mathrm{~min}$, another linear gradient to $100 \%$ solvent B in $5 \mathrm{~min}, 100 \%$ solvent B for $3 \mathrm{~min}$, and finally a linear gradient to $10 \%$ solvent B in $3 \mathrm{~min}$ followed by $10 \%$ solvent B for $3 \mathrm{~min}$. Under these conditions, the compounds were separated with the following retention times: phenol $4.3 \mathrm{~min}$, benzoic acid $4.9 \mathrm{~min},( \pm)$-4-methoxymandelonitrile $5.2 \mathrm{~min}$, 4-anisaldehyde $5.9 \mathrm{~min}$, phenyl benzoate $14.8 \mathrm{~min}$, ( \pm )-4-methoxymandelonitrile benzoate $16.1 \mathrm{~min}$, and mesitylene (internal standard) $19.3 \mathrm{~min}$.

Calibration curves were prepared using commercial 4-anisaldehyde (>99.0\%), (R)-4-methoxymandelonitrile $(98.0 \%)$ and benzoic acid (>99.5\%) as well as chemically synthesized $( \pm)$-4-methoxymandelonitrile benzoate. 


\section{Conclusions}

In the present work, the successful concurrent cascade synthesis of (S)-4-methoxymandelonitrile benzoate starting from 4-anisaldehyde and catalyzed by MeHNL and CALA was accomplished. Systematically studying each enzymatic reaction first was key for their effective combination. When developing the one-pot cascade, however, further fine-tuning of reaction conditions was required to achieve optimal performance. This way, 95\% conversion of 1 with $81 \%$ yield of the final ester (S)-3 and excellent enantiopurity of $98 \%$ e.e. was achieved. Compared to the enzymatic hydrocyanation performed under the same conditions, which yielded 2 with $85 \%$ conversion and $91 \%$ e.e. (see Table 1, entry 9, and Figure S4B), this result proves that the CALA-catalyzed benzoylation of (S)-2 coupled to the $\mathrm{MeHNL}$-catalyzed hydrocyanation of $\mathbf{1}$ can shift the equilibrium of the latter by removal of the unstable intermediate. Nevertheless, there is still room for further improvement, since the low affinity of CALA for cyanohydrin $\mathbf{2}$ has been identified as the main bottleneck that prevents the cascade from reaching full conversion.

In principle, our approach reported herein can be transferred to the synthesis of other acylated cyanohydrins. In any case, a key requirement for success will be the application of a lipase with high selectivity for transesterification over hydrolysis in microaqueous media.

Supplementary Materials: The following are available online at http://www.mdpi.com/2073-4344/9/6/522/s1, Figure S1: Conversion and enantiomeric excess (e.e.) of the remaining 4-methoxymandelonitrile benzoate after $18 \mathrm{~h}$ of hydrolysis reaction, Figure S2: Conversion and enantiomeric excess (e.e.) values obtained for the CALA-catalyzed benzoylation of $67 \mathrm{mM}( \pm)$-4-methoxymandelonitrile using $200 \mathrm{mM}$ vinyl benzoate (VB), acetoxime benzoate (AB) or phenyl benzoate (PB), Figure S3: Comparison of the cascade synthesis of (S)- 4-methoxymandelonitrile benzoate catalyzed by $\mathrm{MeHNL}$ and CALA starting from $100 \mathrm{mM} 1$ (A, Table S2, entry 8) and the hydrocyanation of $100 \mathrm{mM} 1$ catalyzed by MeHNL under the same conditions (B, Table S2, entry 9), Figure S4: Hydrocyanation of $100 \mathrm{mM} 4$-anisaldehyde catalyzed by immobilized MeHNL using 3-6.5 equivalents of $\mathrm{HCN}$ at $20^{\circ} \mathrm{C}$. Table S1: Assigned number and specifications of the lipases screened in the hydrolysis of $( \pm)$-4-methoxymandelonitrile benzoate, Table S2: Results of hydrocyanation of $100 \mathrm{mM} 4$-anisaldehyde with 6.5 equivalents of HCN catalyzed by immobilized $\mathrm{MeHNL}$ in isopropyl ether with $0.34 \mathrm{mmol} \mathrm{Na} 2 \mathrm{HPO}_{4} \cdot 2 \mathrm{H}_{2} \mathrm{O} / \mathrm{Na}_{2} \mathrm{HPO}_{4} \cdot 7 \mathrm{H}_{2} \mathrm{O}$ per mL (water activity of 0.57 ). Detailed information and additional data on the screening of hydrolases for the selective hydrolysis of $( \pm)$-4-methoxymandelonitrile benzoate, the screening of benzoyl donors, the immobilization of $M e H N L$, the effect of $\mathrm{HCN}$ concentration on MeHNL-catalyzed hydrocyanation, the optimized cascade, and the chemical synthesis of ( \pm )-4-methoxymandelonitrile benzoate.

Author Contributions: Conceptualization, L.v.L. and F.H.; methodology, A.S.; validation, L.L., A.S., and L.v.L.; formal analysis, L.L.; investigation, L.L.; resources, A.S., L.v.L. and F.H.; data curation, A.S. and L.v.L.; writing-original draft preparation, L.L. and L.v.L.; writing-review and editing, A.S. and F.H.; visualization, L.L.; supervision, A.S., L.v.L., and F.H..; project administration, A.S. and L.v.L.; funding acquisition, L.v.L., F.H., and A.S.

Funding: This project was funded by the European Union's Horizon 2020 MSCA ITN-EID program under grant agreement No 634200 (BIOCASCADES). This communication reflects only the beneficiary's view and the European Commission is not responsible for any use that may be made of the information it contains.

Acknowledgments: We thank Antje Spieß (Institute of Biochemical Engineering, Technische Universität Braunschweig, Germany) for fruitful discussion and for providing an HPLC system for chiral analysis. L. Leemans also thanks Yvonne Goecke (Institute of Biochemical Engineering, Technische Universität Braunschweig, Germany) for technical support with the HPLC equipment. Further, Kerstin Steiner (ACIB, Graz, Austria) is acknowledged for the generous gift of E. coli K12 Top 10F' clone harboring the pSE420-MeHNL plasmid. Imerys S.A. and Resindion S.r.l. are acknowledged for providing Celite R633 and supplying Relizyme EXE309, respectively.

Conflicts of Interest: The authors declare no conflicts of interest. The funders had no role in the design of the study; in the collection, analyses, or interpretation of data; in the writing of the manuscript, or in the decision to publish the results.

\section{References}

1. Choi, J.M.; Han, S.S.; Kim, H.S. Industrial Applications of Enzyme Biocatalysis: Current Status and Future Aspects. Biotechnol. Adv. 2015, 33, 1443-1454. [CrossRef] [PubMed]

2. Gröger, H.; Asano, Y. Introduction-Principles and Historical Landmarks of Enzyme Catalysis in Organic Synthesis. In Enzyme Catalysis in Organic Synthesis; Drauz, K., Gröger, H., May, O., Eds.; Wiley-VCH Verlag GmbH \& Co. KGaA: Weinheim, Germany, 2012; pp. 1-42. 
3. Sperl, J.M.; Sieber, V. Multienzyme Cascade Reactions-Status and Recent Advances. ACS Catal. 2018, 8, 2385-2396. [CrossRef]

4. France, S.P.; Hepworth, L.J.; Turner, N.J.; Flitsch, S.L. Constructing Biocatalytic Cascades: In Vitro and in Vivo Approaches to de Novo Multi-Enzyme Pathways. ACS Catal. 2017, 7, 710-724. [CrossRef]

5. Gröger, H.; Hummel, W. Combining the "two Worlds" of Chemocatalysis and Biocatalysis towards Multi-Step One-Pot Processes in Aqueous Media. Curr. Opin. Chem. Biol. 2014, 19, 171-179. [CrossRef] [PubMed]

6. Gröger, H.; Hummel, W. Chemoenzymatic Multistep One-Pot Processes. Cascade Biocatal. 2014, 427-456. [CrossRef]

7. Schrittwieser, J.H.; Velikogne, S.; Hall, M.; Kroutil, W. Artificial Biocatalytic Linear Cascades for Preparation of Organic Molecules. Chem. Rev. 2018, 118, 270-348. [CrossRef] [PubMed]

8. Sheldon, R.A.; Arends, I.W.C.E.; Hanefeld, U. Process Integration and Cascade Catalysis. In Green Chemistry and Catalysis; Wiley-VCH Verlag GmbH \& Co. KGaA: Weinheim, Germany, 2007; pp. 389-408.

9. Ricca, E.; Brucher, B.; Schrittwieser, J.H. Multi-Enzymatic Cascade Reactions: Overview and Perspectives. Adv. Synth. Catal. 2011, 353, 2239-2262. [CrossRef]

10. Hanefeld, U.; Straathof, A.J.J.; Heijnen, J.J. Enzymatic Formation and Esterification of (S)-Mandelonitrile. J. Mol. Catal. B Enzym. 2001, 11, 213-218. [CrossRef]

11. Valivety, R.H.; Halling, P.J.; Macrae, A.R. Water as a Competitive Inhibitor of Lipase-Catalysed Esterification in Organic Media. Biotechnol. Lett. 1993, 15, 1133-1138. [CrossRef]

12. Paravidino, M.; Sorgedrager, M.; Orru, R.A.A.; Hanefeld, U. Activity and Enantioselectivity of the Hydroxynitrile Lyase MeHNL in Dry Organic Solvents. Chem. Eur. J. 2010, 16, 7596-7604. [CrossRef]

13. Costes, D.; Wehtje, E.; Adlercreutz, P. Hydroxynitrile Lyase-Catalyzed Synthesis of Cyanohydrins in Organic Solvents Parameters Influencing Activity and Enantiospecificity. Enzyme Microb. Technol. 1999, 25, 384-391. [CrossRef]

14. Persson, M.; Costes, D.; Wehtje, E.; Adlercreutz, P. Effects of Solvent, Water Activity and Temperature on Lipase and Hydroxynitrile Lyase Enantioselectivity. Enzyme Microb. Technol. 2002, 30, 916-923. [CrossRef]

15. Li, Y.-X.; Straathof, A.J.J.; Hanefeld, U. Enantioselective Formation of Mandelonitrile Acetate-investigation of a Dynamic Kinetic Resolution. Tetrahedron Asymmetry 2002, 13, 739-743. [CrossRef]

16. Veum, L.; Kuster, M.; Telalovic, S.; Hanefeld, U.; Maschmeyer, T. Enantioselective Synthesis of Protected Cyanohydrins. Eur. J. Org. Chem. 2002, 2002, 1516-1522. [CrossRef]

17. Veum, L.; Hanefeld, U. Enantioselective Formation of Mandelonitrile Acetate: Investigation of a Dynamic Kinetic Resolution II. Tetrahedron Asymmetry 2004, 15, 3707-3709. [CrossRef]

18. Veum, L.; Hanefeld, U. Enantioselective Synthesis of Aliphatic Cyanohydrin Acetates. Synlett 2005, 15, 2382-2384. [CrossRef]

19. Hietanen, A.; Ekholm, F.S.; Leino, R.; Kanerva, L.T. Applying Biocatalysis to the Synthesis of Diastereomerically Enriched Cyanohydrin Mannosides. Eur. J. Org. Chem. 2010, 2010, 6974-6980. [CrossRef]

20. Hietanen, A.; Kanerva, L.T. One-Pot Oxidation-Hydrocyanation Sequence Coupled to Lipase-Catalyzed Diastereoresolution in the Chemoenzymatic Synthesis of Sugar Cyanohydrin Esters. Eur. J. Org. Chem. 2012, 2012, 2729-2737. [CrossRef]

21. Okrob, D.; Paravidino, M.; Orru, R.V.A.; Wiechert, W.; Hanefeld, U.; Pohl, M. Hydroxynitrile Lyase from Arabidopsis thaliana: Identification of Reaction Parameters for Enantiopure Cyanohydrin Synthesis by Pure and Immobilized Catalyst. Adv. Synth. Catal. 2011, 353, 2399-2408. [CrossRef]

22. Malona, J.A.; Cariou, K.; Spencer, W.T.; Frontier, A.J. Total Synthesis of ( \pm )-Rocaglamide via Oxidation-Initiated Nazarov Cyclization. J. Org. Chem. 2012, 77, 1891-1908. [CrossRef]

23. Yildirim, D.; Tükel, S.S.; Alagöz, D. Crosslinked Enzyme Aggregates of Hydroxynitrile Lyase Partially Purified from Prunus dulcis Seeds and Its Application for the Synthesis of Enantiopure Cyanohydrins. Biotechnol. Prog. 2014, 30, 818-827. [CrossRef] [PubMed]

24. Van Langen, L.M.; Van Rantwijk, F.; Sheldon, R.A. Enzymatic Hydrocyanation of a Sterically Hindered Aldehyde. Optimization of a Chemoenzymatic Procedure for $(R)$-2-Chloromandelic Acid. Org. Process Res. Dev. 2003, 7, 828-831. [CrossRef]

25. Veum, L.; Pereira, S.R.M.; Van Der Waal, J.C.; Hanefeld, U. Catalytic Hydrogenation of Cyanohydrin Esters as a Novel Approach to N-Acylated $\beta$-Amino Alcohols-Reaction Optimisation by a Design of Experiment Approach. Eur. J. Org. Chem. 2006, 2006, 1664-1671. [CrossRef] 
26. Cheng, M.J.; Lee, K.H.; Tsai, I.L.; Chen, I.S. Two New Sesquiterpenoids and Anti-HIV Principles from the Root Bark of Zanthoxylum ailanthoides. Bioorg. Med. Chem. 2005, 13, 5915-5920. [CrossRef] [PubMed]

27. Shoeb, A.; Kapil, R.S.; Popli, S.P. Coumarins and Alkaloids of Aegle marmelos. Phytochemistry 1973, 12, 2071-2072. [CrossRef]

28. Semba, H.; Dobashi, Y.; Matsui, T. Expression of Hydroxynitrile Lyase from Manihot esculenta in Yeast and Its Application in (S)-Mandelonitrile Production Using an Immobilized Enzyme Reactor. Biosci. Biotechnol. Biochem. 2008, 72, 1457-1463. [CrossRef]

29. Müller, J.; Sowa, M.A.; Fredrich, B.; Brundiek, H.; Bornscheuer, U.T. Enhancing the Acyltransferase Activity of Candida antarctica Lipase A by Rational Design. ChemBioChem 2015, 16, 1791-1796. [CrossRef]

30. Phillips, R.S. Temperature Modulation of the Stereochemistry of Enzymatic Catalysis: Prospects for Exploitation. Trends Biotechnol. 1996, 14, 13-16. [CrossRef]

31. Dadashipour, M.; Asano, Y. Hydroxynitrile Lyases: Insights into Biochemistry, Discovery and Engineering. ACS Catal. 2011, 1, 1121-1149. [CrossRef]

32. Willeman, W.F.; Straathof, A.J.J.; Heijnen, J.J. Reaction Temperature Optimization Procedure for the Synthesis of (R)-Mandelonitrile by Prunus amygdalus Hydroxynitrile Lyase Using a Process Model Approach. Enzyme Microb. Technol. 2002, 30, 200-208. [CrossRef]

33. Ueatrongchit, T.; Tamura, K.; Ohmiya, T.; H-Kittikun, A.; Asano, Y. Hydroxynitrile Lyase from Passiflora edulis: Purification, Characteristics and Application in Asymmetric Synthesis of (R)-Mandelonitrile. Enzyme Microb. Technol. 2010, 46, 456-465. [CrossRef] [PubMed]

34. Willeman, W.F.; Hanefeld, U.; Straathof, A.J.J.; Heijnen, J.J. Estimation of Kinetic Parameters by Progress Curve Analysis for the Synthesis of (R)-Mandelonitrile by Prunus amygdalus Hydroxynitrile Lyase. Enzyme Microb. Technol. 2000, 27, 423-433. [CrossRef]

35. O'Neil, M.J.; Patricia, E.; Heckelman, A.S.; Budavari, S. The Merck Index-An Encyclopedia of Chemicals Drugs and Biologicals; Merck and Co.: Whitehouse Station, NJ, USA, 2006; p. 830.

36. Shakeri, M.; Engström, K.; Sandström, A.G.; Bäckvall, J.E. Highly Enantioselective Resolution of $\beta$-Amino Esters by Candida antarctica Lipase A Immobilized in Mesocellular Foam: Application to Dynamic Kinetic Resolution. ChemCatChem 2010, 2, 534-538. [CrossRef]

37. Ding, W.; Li, M.; Dai, R.; Deng, Y. Lipase-Catalyzed Synthesis of the Chiral Tetrahydroisoquinoline (R)-Salsolinol. Tetrahedron Asymmetry 2012, 23, 1376-1379. [CrossRef]

38. Zamost, B.L.; Nielsen, H.K.; Starnes, R.L. Thermostable Enzymes for Industrial Applications. J. Ind. Microbiol. 1991, 8, 71-81. [CrossRef]

39. Adlercreutz, P. Immobilisation and Application of Lipases in Organic Media. Chem. Soc. Rev. 2013, 42, 6406-6436. [CrossRef] [PubMed]

40. Bastida, A.; Sabuquillo, P.; Armisen, P.; Fernández-Lafuente, R.; Huguet, J.; Guisán, J.M. A Single Step Purification, Immobilization, and Hyperactivation of Lipases via Interfacial Adsorption on Strongly Hydrophobic Supports. Biotechnol. Bioeng. 1998, 58, 486-493. [CrossRef]

41. Hanefeld, U. Immobilisation of Hydroxynitrile Lyases. Chem. Soc. Rev. 2013, 42, 6308-6321. [CrossRef]

42. Cabirol, F.L.; Hanefeld, U.; Sheldon, R.A. Immobilized Hydroxynitrile Lyases for Enantioselective Synthesis of Cyanohydrins: Sol-Gels and Cross-Linked Enzyme Aggregates. Adv. Synth. Catal. 2006, 348, 1645-1654. [CrossRef]

43. Valivety, R.H.J.; Halling, P.; Macrae, A.R. Reaction Rate with Suspended Lipase Catalyst Shows Similar Dependence on Water Activity in Different Organic Solvents. Biochim. Biophys. Acta (BBA)/Protein Struct. Mol. 1992, 1118, 218-222. [CrossRef]

44. Schmitke, J.L.; Wescott, C.R.; Klibanov, A.M. The Mechanistic Dissection of the Plunge in Enzymatic Activity upon Transition from Water to Anhydrous Solvents. J. Am. Chem. Soc. 1996, 118, 3360-3365. [CrossRef]

45. Wehtje, E.; Costes, D.; Adlercreutz, P. Enantioselectivity of Lipases: Effects of Water Activity. J. Mol. Catal. B Enzym. 1997, 3, 221-230. [CrossRef]

46. Pepin, P.; Lortie, R. Influence of Water Activity on the Enantioselective Esterification of $(R, S)$-Ibuprofen by Candida antarctica Lipase B in Solventless Media. Biotechnol. Bioeng. 1999, 63, 502-505. [CrossRef]

47. Bovara, R.; Carrea, G.; Ottolina, G.; Riva, S. Water Activity Does Not Influence the Enantioselectivity. Biotechnol. Lett. 1993, 15, 169-174. [CrossRef]

48. Carrea, G.; Riva, S. Properties and Synthetic Applications of Enzymes in Organic Solvents. Angew. Chem. Int. Ed. Engl. 2000, 39, 2226-2254. [CrossRef] 
49. Lauble, H.; Miehlich, B.; Förster, S.; Wajant, H.; Effenberger, F. Crystal Structure of Hydroxynitrile Lyase from Sorghum bicolor in Complex with the Inhibitor Benzoic Acid: A Novel Cyanogenic Enzyme. Biochemistry 2002, 41, 12043-12050. [CrossRef]

50. Xu, L.L.; Singh, B.K.; Conn, E.E. Purification and Characterization of Mandelonitrile Lyase from Prunus lyonii. Arch. Biochem. Biophys. 1986, 250, 322-328. [CrossRef]

51. Jaenicke, L.; Preun, J. Chemical Modification of Hydroxynitrile Lyase by Selective Reaction of an Essential Cysteine-SH Group with $\alpha, \beta$-unsaturated Propiophenones as Pseudo-substrates. Eur. J. Biochem. 1984, 138, 319-325. [CrossRef]

52. Hanefeld, U.; Straathof, A.J.J.; Heijnen, J.J. Study of the (S)-Hydroxynitrile Lyase from Hevea brasiliensis: Mechanistic Implications. Biochim. Biophys. Acta-Protein Struct. Mol. Enzymol. 1999, 1432, $185-193$. [CrossRef]

53. Lowe, M.E. Assays for Pancreatic Triglyceride Lipase and Colipase. In Lipase and Phospholipase Protocols. Methods in Molecular Biology; Doolittle, M., Reue, K., Eds.; Humana Press: New York, NY, USA, 1999; Volume 109, pp. 59-70.

54. Schallmey, M.; Jekel, P.; Tang, L.; Elenkov, M.M.; Höffken, H.W.; Hauer, B.; Janssen, D.B. A single point mutation enhances hydroxynitrile synthesis by halohydrin dehalogenase. Enzyme Microb. Technol. 2015, 70, 50-57. [CrossRef]

55. Chen, C.; Fujimoto, Y.; Girdaukas, G.; Sih, C.J. Quantitative Analyses of Biochemical Kinetic Resolutions of Enantiomers. J. Am. Chem. Soc. 1982, 104, 7294-7299. [CrossRef]

56. Sakuth, M.; Mensing, T.; Schuler, J.; Heitmann, W.; Strehlke, G.; Mayer, D. Ethers, Aliphatic. In Ullmann's Encyclopedia of Industrial Chemistry, 6th ed.; Elvers, B., Ed.; Wiley-VCH Verlag GmbH \& Co. KGaA: Weinheim, Germany, 2012; p. 440.

57. Halling, P.J. Salt Hydrates for Water Activity Control with Biocatalysts in Organic Media. Biotechnol. Tech. 1992, 6, 271-276. [CrossRef]

(C) 2019 by the authors. Licensee MDPI, Basel, Switzerland. This article is an open access article distributed under the terms and conditions of the Creative Commons Attribution (CC BY) license (http://creativecommons.org/licenses/by/4.0/). 